\title{
Treatment of Ulcerative Colitis with Azathioprine
}

\author{
EMANUEL THEODOR,* M.D. ; ELIAHU GILON,* M.D. ; UZI WAKS,* M.D.
}

Brit. med. F., 1968, 4, 741-743

\begin{abstract}
Cummary : Azathioprine (Imuran) was administered to $N$ seven patients with ulcerative colitis suffering from a relapse which could not be controlled by adrenocortical steroids. In four patients remission started one to two weeks after initiation of antimetabolite therapy. Corticosteroid administration was continued concurrently with azathioprine, but the dosage could be reduced and in one case they were withdrawn.
\end{abstract}

Apart from transient leucopenia in two cases, and transient nausea and vomiting in two, no complications were encountered.

Antimetabolites have been used in the treatment of ulcerative colitis with success (Bean, 1966a , Bowen et al., 1966 ; Mackay et al., 1966 ; Swanson and Schwartz, 1967). Some authors (Avery Jones et al., 1966 ; Bowen et al., 1966 ; Mackay et al., 1966) encountered toxic side-effects, including severe leucopenia and alopecia, but large doses were given to some of their patients $(6 \mathrm{mg} . / \mathrm{kg}$./day of azathioprine (Imuran) (Bowen et al., 1966), $600 \mathrm{mg}$./day (Mackay et al., 1966)). Adrenocortical steroids were often given concomitantly with antimetabolites in varying dosage schedules, but remissions were also achieved without their addition.

Published reports have not emphasized an important point -namely, that antimetabolites can induce a remission in ulcerative colitis when other therapy, including corticosteroids, has failed.

The present report describes our experience with antimetabolite therapy in cases of severe ulcerative colitis not responding to conventional doses of corticosteroids.

\section{Case 1}

This 32-year-old man had been suffering from ulcerative colitis since February 1966. He did not respond to azosulfidine or hydrocortisone enemas, and had to receive a maintenance dose of 40 $\mathrm{mg} . /$ day of prednisone to control his diarrhoea.

He was admitted with an exacerbation on 1 March 1967. Barium enema showed the colon to be involved from the midtransverse colon distally. There was no improvement on continuous administration of $60 \mathrm{mg}$. of prednisone per day for one month. $\mathrm{He}$ also developed acute arthritis of one knee during this time. Azathioprine, $150 \mathrm{mg}$./day, was then started. After one week his diarrhoea stopped and blood in the stools decreased to trace amounts. At this point prednisone was quickly tapered until stopped. The diarrhoea returned, but responded to resumption of prednisone in a dose of $30 \mathrm{mg}$./day and increase in the dose of azathioprine to $200 \mathrm{mg}$./day. Further exacerbations occurred on decrease and then discontinuation of azathioprine. The patient has been well since September 1967, there being marked improvement in sigmoidoscopic findings, but little change on barium enema. He continues to be maintained on prednisone $20 \mathrm{mg}$./day. He has gained $15 \mathrm{~kg}$. in weight compared with his weight at the height of his illness and is employed as a manual labourer.

Comment.-The response in this case was erratic, presumably because of too rapid changes in dosage of both drugs. Still, it appears that, while the diarrhoea was not controlled on fairly large doses of corticosteroids initially, it was well \footnotetext{
* Department of Medicine, Tel-Hashomer Government Hospital,
Tel-Aviv, Israel.
}

Reprints may be obtained from Dr. E. Theodor. controlled on smaller doses subsequently, during and after azathioprine therapy.

\section{Case 2}

A 54-year-old woman was first admitted to hospital in 1966 for severe ulcerative colitis, with generalized colitis and pseudopolyposis on barium enema. She entered remission after one month's therapy with corticosteroids and azosulfidine. In February 1967 she had a relapse, and in March entered hospital for the second time She did not improve on prednisone-60 and then $80 \mathrm{mg}$./day-hydrocortisone enemas, and azosulfidine. She lost $7 \mathrm{~kg}$. (16.6 lb.) in weight and had continuous tenesmus and severe pain on defaecation. Barium enema showed findings similar to those noted on her previous admission. Sigmoidoscopy showed active mucosal disease with pseudopolyposis. Mercaptopurine administration was started in a dose of $300 \mathrm{mg}$./day, but because of nausea and vomiting it was stopped after a week, and azathioprine $150 \mathrm{mg}$./day was started. Prednisone administration was continued, the dose being gradually decreased to $10 \mathrm{mg} . /$ day (Fig. 1). Eleven days after antimetabolites were started the diarrhoea stopped, the patient's general condition improved, and she began to gain weight. Because of leucopenia of 2,000 W.B.C./cu.mm. azathioprine dosage was temporarily reduced to $100 \mathrm{mg}$./day. She had a mild relapse when prednisone was discontinued temporarily, and another one when azathioprine was stopped after seven moriths.
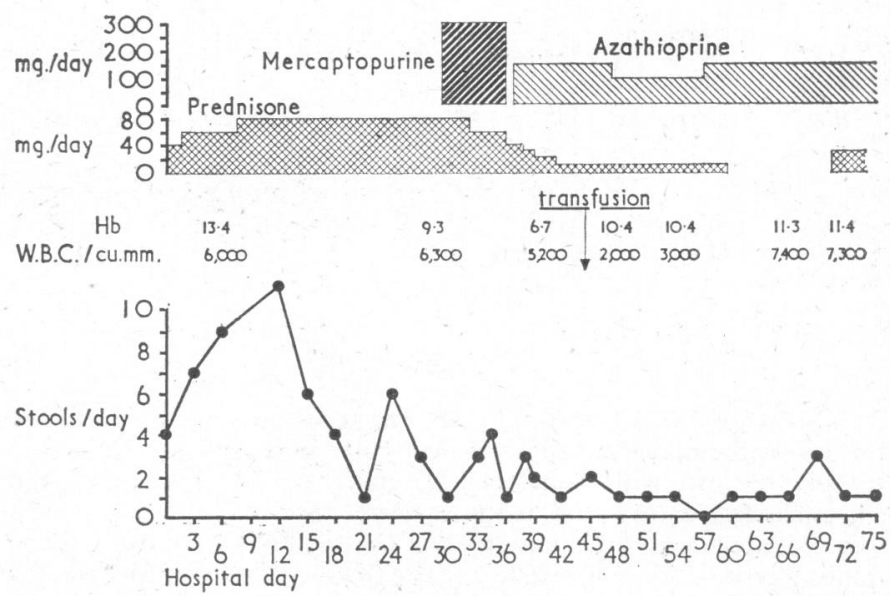

FIg. 1.-Course in Case 2.

The patient continued to do well on a maintenance dose of 20 mg. of prednisone per day. Sigmoidoscopy performed after three months of antimetabolite therapy showed that the pseudopolyposis and signs of active inflammation had disappeared. A repeat barium enema was essentially unchanged.

Comment.-At the start of antimetabolite therapy the patient's condition was serious-much more so than would be indicated by the number of stools in Fig. 1. Colectomy was seriously considered, but the patient is severely neurotic, with conversive reactions, so that a permanent ileostomy was out of the question. Since successful control of the relapse we have been able to avoid surgery, at least for the present.

\section{Case 3}

This 16-year-old boy started to have diarrhoea one month before admission. Initially the stools contained oome blood, and later the diarrhoea was watery. The patient lost $6 \mathrm{~kg}$. in weight. 
On admission he was cachectic, with widespread ecchymoses in the skin and oedema of the ankles. He had a fever rising to $38.6^{\circ}$ C. and anaemia, and the serum albumin reached as low as 1.9 g./ $100 \mathrm{ml}$. Barium enema and sigmoidoscopy showed the presence of generalized ulcerative colitis with pseudopolyposis. He was given blood, plasma, and albumin transfusion, together with massive corticosteroid therapy, but his condition worsened until he could not move from his bed. He appeared to be dying. After one month in hospital he was given azathioprine, with reduction in steroid dosage (Fig. 2). Within two weeks he began to improve; the number of stools per day decreased and became formed, his appetite improved, and he began to gain weight while his oedema disappeared. The haemoglobin and serum albumin rose. After three months in hospital he was discharged, and on follow-up visits he continued to improve and was taking azathioprine $100 \mathrm{mg}$./day.

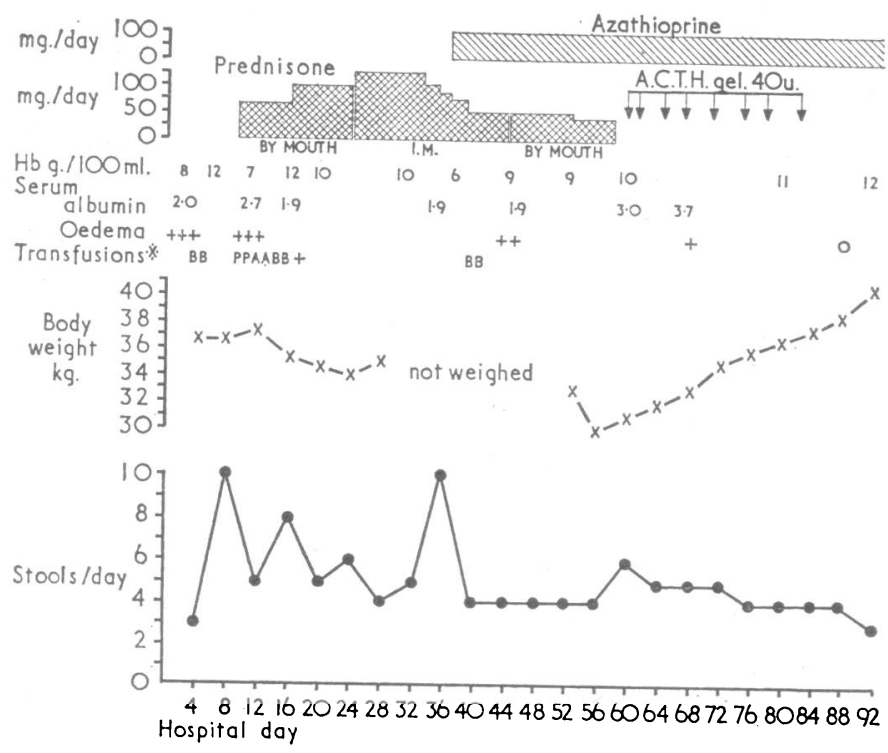

Frg. 2.-Course in Case 3. ${ }^{*} \mathrm{~B}=$ blood, $\mathrm{A}=$ albumin, $\mathrm{P}=$ plasma.

Comment.-In this case azathioprine therapy clearly reversed a steady downhill course in a patient who was considered to be too ill to undergo colectomy.

\section{Case 4}

This patient, a 22-year-old man, began to have bloody diarrhoea in the middle of 1965. Sigmoidoscopy in November revealed a raw, friable mucosa with superficial ulcerations. Stool cultures and examination for ova and parasites were negative. Barium enema showed irregularity of the mucosa of the sigmoid and rectum. The patient responded to azosulfidine, $6 \mathrm{~g}$./day, and the sigmoidoscopic findings improved markedly within two weeks.

He was asymptomatic without therapy until August 1966, when he again had diarrhoea, four bowel movements daily, containing blood and pus. Sigmoidoscopy in April 1967 again showed an oedematous friable mucosa covered with purulent exidate. $\mathrm{He}$ responded to prednisone, but medication could not be discontinued for eight months because of relapses on reduction of the dose.

On 15 January 1968 azathioprine $3 \mathrm{mg} . / \mathrm{kg}$./day was started, while he continued to take prednisone $30 \mathrm{mg} . /$ day. After one week azathioprine dosage was halved for three days because of nausea and then the initial does was resumed, without further difficulty. After 14 days remission started and was maintained on decreasing doses of azathioprine and prednisone. He now feels completely well, and has one formed bowel movement a day with no rectal bleeding.

\section{Case 5}

This 19-year-old man was affected by ulcerative colitis six weeks before admission. He did not respond to azosulfidine or infusions of adrenocorticotrophin. On $60 \mathrm{mg}$./day of prednisone his fever promptly resolved and he began to improve. After nine days the dose of prednisone was rapidly tapered, and within a few days the patient had a relapse. While prednisone was being reduced and then discontinued, azathioprine $3 \mathrm{mg} . / \mathrm{kg}$./day was started. Since two weeks of azathioprine therapy had no effect, and a leucopenia of 2,600 W.B.C./cu.mm. developed, this medication was discontinued. The patient then entered remission on resumption of prednisone, $60 \mathrm{mg}$./day.

Comments.-Here prednisone was given for too short a time to judge its effectiveness. As in Case 1, the drug was reduced very quickly on initiation of azathioprine therapy, and probably the relapse due to premature steroid withdrawal overshadowed any pussible effect of azathioprine.

\section{Case 6}

This 18-year-old girl had been suffering from ulcerative colitis since 1963. She was admitted with a severe exacerbation while on a maintenance dose of prednisone of $10 \mathrm{mg} . /$ day. On the day of admission she had 24 bowel movements, consisting mostly of blood and pus. Prednisone and azosulfidine brought some improvement. An exacerbation occurred on interruption of azosulfidine (because of nausea), and remission was then achieved with azathioprine and increased doses of prednisone.

It is of note that several of the patient's stool cultures were positive for salmonella, and she received antibiotics in addition to the medication mentioned. It is therefore impossible to be certain which therapeutic agent brought on her remission.

\section{Case 7}

This patient, a 30-year-old man, began to have diarrhoea with blood and pus in the stools in November 1967. He was admitted in January 1968, and ulcerative colitis was diagnosed, a barium enema showing the disease process to extend from the midtransverse colon distally. Remission seemed to start on prednisone, but he had a relapse after the barium enema, and responded only partially to prednisone $60 \mathrm{mg}$./day. The patient was then given azathioprine

Response of Patients to Antimetabolic Therapy

\begin{tabular}{|c|c|c|c|c|c|c|c|c|}
\hline $\begin{array}{l}\text { Case } \\
\text { No. }\end{array}$ & Age & Sex & $\begin{array}{c}\text { Therapy } \\
\text { Immediately Preceding } \\
\text { Antimetabolites }\end{array}$ & $\begin{array}{l}\text { Azathioprine } \\
\text { (mg/kg./day) }\end{array}$ & \begin{tabular}{c|} 
Onset \\
Remission, \\
Days after \\
Starting \\
Antimetabolites
\end{tabular} & $\begin{array}{c}\text { Duration of } \\
\text { Antimetabolite } \\
\text { Therapy }\end{array}$ & $\begin{array}{l}\text { Control } \\
\text { of } \\
\text { Episode }\end{array}$ & Remarks \\
\hline 1 & 32 & $\mathbf{M}$ & $\begin{array}{l}\text { Prednisone } 60 \mathrm{mg} . / \text { day for } \\
28 \text { days }\end{array}$ & $2 \cdot 5-3$ & 7 & 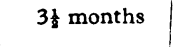 & Yes & $\begin{array}{l}\text { Prednisone stopped at start of anti- } \\
\text { metabolite therapy, then resumed }\end{array}$ \\
\hline 2 & 54 & $\mathbf{F}$ & $\begin{array}{l}\text { Prednisone } 80 \mathrm{mg} . / \text { day for } \\
30 \text { days }\end{array}$ & $3^{*}$ & 11 & 7 months & Yes & \\
\hline 3 & 16 & $\mathbf{M}$ & $\begin{array}{l}\text { Prednisone } 60-125 \mathrm{mg} . / \mathrm{day} \\
\text { for } 28 \text { days }\end{array}$ & 3 & 14 & $\begin{array}{l}\text { Started } \\
16 \text { Oct. } 1967\end{array}$ & Yes & \\
\hline 4 & 22 & $\mathbf{M}$ & $\begin{array}{l}\text { Prednisone, } 10-40 \mathrm{mg} . / \text { day } \\
\text { for } 240 \text { days }\end{array}$ & 3 & 14 & Started & Yes & \\
\hline 5 & 19 & $M$ & $\begin{array}{l}\text { Prednisone, } 30-60 \mathrm{mg} . / \text { day } \\
\text { for } 14 \text { days }\end{array}$ & 3 & - & 13 days & No & $\begin{array}{l}\text { Prednisone stopped at start of anti- } \\
\text { metabolite therapy }\end{array}$ \\
\hline 6 & 18 & $\mathbf{F}$ & $\begin{array}{l}\text { Prednisone, } 25-60 \mathrm{mg} . / \text { day } \\
\text { for } 23 \text { days }\end{array}$ & 3 & See remarks & 5 months & Questionable & $\begin{array}{l}\text { Salmonella treated and prednisone } \\
\text { increased concurrently with start of } \\
\text { antimetabohite }\end{array}$ \\
\hline 7 & 30 & $\mathbf{M}$ & $\begin{array}{l}\text { Prednisone, } 30-60 \mathrm{mg} . / \text { day } \\
\text { for } 30 \text { days }\end{array}$ & $2-4$ & 40 & $\begin{array}{l}\text { Started } \\
22 \text { Feb. } 1968\end{array}$ & No & $\begin{array}{l}\text { Remission probably unrelated to anti- } \\
\text { metabolite }\end{array}$ \\
\hline
\end{tabular}


$3 \mathrm{mg} . / \mathrm{kg} . /$ day, while prednisone was continued. There was a slight decrease in the number of stools and the amount of blood passed. However, he continued to lose weight and developed progressive iron-deficiency anaemia.

After two months in hospital he began to gain weight and passed formed stools without blood, while the anaemia responded to parenteral iron. Sigmoidoscopy before discharge showed that he had greatly improved.

Comment.-The continued activity of the disease while the patient was receiving azathioprine, and the delayed remission, seem to show that the course in this case was unaffected by the antimetabolite.

The accompanying Table presents collected data on the patients' response to therapy.

\section{Discussion}

In the present series four out of seven patients with ulcerative colitis started remission on antimetabolites after they had failed to do so on adrenocortical steroid therapy.

Since the relapse encountered in Cases 1 and 5 upon steroid withdrawal at the time antimetabolite therapy was initiated we have made it our practice to continue steroid medication concomitantly with the antimetabolite. However, after beginning the latter therapy smaller doses of steroids were needed in Cases 1, 2, and 4, in which larger doses had been only partially effective or had had no effect. This would parallel the "steroidsparing effect" reported by several authors when "autoimmune" diseases were treated by antimetabolites (Bowen et al., 1966 ; Clinical Staff Conference, 1963 ; Mackay et al., 1964). It is of note that remissions have been achieved in ulcerative colitis by antimetabolites alone (Bowen et al., 1966 ; Mackay et al., 1966; Swanson and Schwartz, 1967). This could be of importance in cases where corticosteroids are contraindicated because of complications resulting from their use, or because of underlying disease. Further information on the place of steroid-antimetabolite combinations in the treatment of ulcerative colitis is clearly needed.

In the meantime it seems logical to continue steroid therapy, which is usually tried before antimetabolites, together with the latter medication, and to attempt gradual decrease in dosage of steroids or their complete withdrawal only when remission has begun.

The mechanism of action of antimetabolites in "autoimmune" diseases is not clear. There is poor correlation of clinical response with suppression of various immunological responses, of either the immediate or the delayed type (Bean, 1966b; Swanson and Schwartz, 1967). The clinical effect might conceivably be due to a nonspecific suppression of the inflammatory response (Page et al., 1962 ; Demis et al., 1964 ; Page, 1964 ; and Hersh et al., 1966). Either immunosupression or the anti-inflammatory effect may explain the marked decrease in the inflammatory infiltrate observed in rectal biopsies after ulcerative colitis is treated with antimetabolites (Bowen et al., 1966 ; Bean, 1966a ; and Mackay et al., 1966).

A cause for concern is the suppression of bone marrow by antimetabolites, with leucopenia which can be severe. However, this can be reversed by reduction of dosage or withdrawal of medication (Clinical Staff Conference, 1963; Mackay et al., 1966), as also shown in our cases, and does not usually constitute a hazard. While severe infections do occur in patients with " autoimmune" diseases receiving antimetabolite therapy, their incidence seems to be much lower than in patients after renal transplantation undergoing this treatment (Swanson and Schwartz, 1967), and the risk seems to be justified in view of the serious nature of the diseases being treated.

Apart from general supportive measures, the means of proved value which are at present at our disposal for the medical management of ulcerative colitis are limited to azosulfidine and adrenocortical steroids. Once these fail the alternative is total colectomy. Any therapeutic modality which may postpone or replace surgery warrants a thorough trial, especially since this mutilating operation is often needed in young patients. (Obviously the indication for surgery here discussed is acute ulcerative colitis, not " surgical" complications or carcinoma.) We therefore feel that further experience should be gained with antimetabolites in the treatment of severe ulcerative colitis; while they are effective in only a proportion of the cases treated, they offer an additional therapeutic modality which carries a relatively minor risk.

There is no indication in the literature that ulcerative colitis is cured by antimetabolites. Their value seems to lie in the induction of remissions, like the previously mentioned agents. However, since each individual relapse of ulcerative colitis can cause severe disability or even death, the control of each episode will have to remain the aim of therapy until such time as a cure is found for this disease.

\section{Addendum}

Case 2.-After discontinuing azathioprine therapy in midNovember 1967 this patient's remission was maintained on $20 \mathrm{mg}$. of prednisone daily for eight months. She then entered hospital in severe relapse, and when she did not respond to large doses of oral prednisone and intravenous A.C.T.H. azathioprine therapy was resumed. Within a few days severe anaemia and leucopenia appeared, and azathioprine was discontinued. The white cell count reached a minimum of $1,200 / \mathrm{cu}$. mm.; high fever and prostration appeared. These responded rapidly to antibiotics and intravenous hydrocortisone, and the patient then agreed to undergo colectomy. While being prepared for surgery with blood and plasma transfusions (given for anaemia and hypoproteinaemia), and while the white cell count began to rise, she died suddenly-four days after subsidence of the high fever. At necropsy the only finding was universal ulcerative colitis with pseudopolyposis. There was no gross or microscopical evidence of septicaemia.

\section{REFERENCES}

Avery Jones, F., Lennard-Jones, J. E., Hinton, J. M., and Reeves, W. G. (1966). Brit. med. Ұ., 1, 1418.

Bean, R. H. D. (1966a). Brit. med. F., 1, 1081.

Bean, R. H. D. (1966b). Brit. med. F., 2, 361.

Bowen, G. E., Irons, G. V., Rhodes, J. B., and Kirsner, J. B. (1966). f. Amer. med. Ass., 195, 460 .

Clinical Staff Conference (1963). Ann. intern. Med., 59, 388.

Demis, D. J., Brown, C. S., and Crosby, W. H. (1964). Amer. F. Med., 37, 195.

Hersh, E. M., Wong, V. G., and Freireich, E. J. (1966). Blood, 27, 38. Mackay, I. R., Weiden, S., and Ungar, B. (1964). Lancet, 1, 899.

Mackay, I. R., Wall, A. J., and Goldstein, G. (1966). Amer. F. Dig. Dis., 11, 536.

Page, A. R. (1964). Ann. N.Y. Acad. sci., 116, 950.

Page, A. R., Condie, R. M., and Good, R. A. (1962). Amer. 7. Path., 40, 519.

Swanson, M. A., and Schwartz, R. S. (1967). New Engl. F. Med., 277, 163. 